\title{
Linguistic Varieties in Homegoing: Translating the Other's Voice into Spanish
}

\author{
Author: \\ Miguel Sanz Jiménez \\ Universidad Complutense de Madrid, Spain \\ miguelsanz@ucm.es \\ https://orcid.org/0000-0001-7720-2004 \\ Date of reception: 29/03/2021 \\ Date of acceptance: $28 / 07 / 2021$ \\ Citation: \\ Sanz Jiménez, Miguel. 2022. "Linguistic Varieties \\ in Homegoing: Translating the Other's Voice into \\ Spanish." Alicante Journal of English Studies 36: \\ 149-171. \\ https://doi.org/10.14198/raei.2022.36.08 \\ (C) 2022 Miguel Sanz Jiménez \\ Licence: This work is licensed under a Creative \\ Commons Attribution 4.0 International License \\ (CC BY 4.0).

\section{(c) (1)}

\section{Miguel SAnZ JimÉnEZ}

\begin{abstract}
:
The objective of this paper is to study the Spanish translation of Yaa Gyasi's Homegoing (2016), a novel that adopts the form of a neo-slave narrative to chronicle a black family's history from eighteenth-century Ghana to the early twenty-first century in the United States. The contexts in which both the source and target text were published will be described, paying attention to paratexts, to the book's reception, and to the translation's positive reviews. Gyasi's debut oeuvre depicts alterity and the non-standard linguistic varieties, such as Black English, spoken by the dispossessed Other. This paper examines the strategies that the translator, Maia Figueroa (2017), has made use of to render this interplay of voices into Spanish. In addition, it considers how her choice to standardize some fragments and to introduce marked non-standard language in certain passages affects the reflection of the narrative Us vs. Otherness in the target text.
\end{abstract}

Keywords: African American literature; Black English; linguistic varieties; literary translation English-Spanish; Yaa Gyasi 


\section{Introduction}

This paper studies Homegoing's Spanish translation by Maia Figueroa, which was published in 2017 by Salamandra. It is Yaa Gyasi's debut novel (2016) and it begins with Maame's daughters, Effia and Esi, who are born in Ghana in the eighteenth century. Effia marries a British settler and lives in Africa while Esi is kidnapped, sold into slavery, experiences the horrors of the Middle Passage ${ }^{1}$ and ends up working in a cotton plantation in the South of the United States. Homegoing follows their descendants up to the early twenty-first century, it depicts several linguistic varieties and complies with some of the conventions of neo-slave narratives in the sense that it portrays the traumatic experiences and memories of slavery that have marked several generations of African Americans, as will be explained below.

The term "neo-slave narratives" was coined by Bell in reference to the "modern narratives of escape from bondage to freedom" $(1987,289)$ that emerged in the 1960s in the United States. Partly as a consequence of the Civil Rights Movement and its influence on the representation of slavery in fiction, black writers argued that the reconstruction of the first texts that articulated African American subjectivity—slave narratives like that of Frederick Douglasscould, as Dubey puts it, help "discuss the issues concerning contemporary racial identities" $(2010,333)$. When considering how neo-slave narratives shed light on the hidden history of black Americans, Rushdy (1992, 375-376) classifies such novels in the following four categories: stories of slavery in the South before the Civil War that may be narrated by a former slave, like James McBride's The Good Lord Bird (2013); contemporary novels featuring black people whose ancestors were slaves and who are now dealing with the consequences of this family trauma, as in Octavia E. Butler's Kindred (1979); books that play with the conventions of nineteenth-century slave narratives and rewrite them from a postmodern perspective, ${ }^{2}$ like Ishmael Reed's Flight to Canada (1976); and novels that trace a black family's history back to their enslaved ancestors and represent the memories of slavery carried down from one generation to the next, as in Gyasi's Homegoing, especially the chapters that follow Esi's descendants.

This paper follows the tenets of Descriptive Translation Studies, so it does not prescribe how Figueroa should have rendered Gyasi's novel into Spanish.

1 A term used to describe "the voyage of slaving vessels from African to American ports [...] Abolitionists and then historians have used descriptions of the treatment of slaves aboard ships, the terror experienced by the captives, and the high mortality rates on some of the voyages to demonstrate some of slavery's worst aspects" (Rodriguez 2007, 381).

2 Dubey $(2010,339)$ labels this neo-slave narratives as historiographic metafiction or "postmodern novels that playfully parody established forms of historical writing." 
Instead, this study examines "coupled pairs of translational problems and their corresponding translational solutions" (Toury 1985, 25) in Tables 1 to 7 in order to observe how otherness, particularly blackness, ${ }^{3}$ is represented in both Homegoing and its Spanish translation. The first step is to study the contexts in which the source and target texts were published. To contextualize Gyasi's book and the translation, the paratexts that go with Homegoing need to be analyzed. Paratexts are "those elements in a published work that accompany the text" (Braga Riera 2018, 249) and they give readers "the possibility of either stepping inside or turning back" and not reading the text (Gennette 1997, 2). Paratexts combine linguistic and visual elements to attract the reader's attention, to explain the content and also to guide the reading. Paratexts are divided into peritext and epitext. The former refers to "footnotes and endnotes, prefaces and forewords, introductions, epilogues or afterwords, postscripts, dedications, acknowledgements, index, titles and subtitles, chapter synopsis and headings" (Braga Riera 2018, 249), as well as to visual features like illustrations and cover and dust jacket design. The epitext, is defined as "any paratext not materially appended to the text" (Genette 1997, 344) and it mainly comprises reviews and interviews with the writer, as well as publicity posters, book tours and signings at book fairs. Peritext and epitext may influence the reception of a translated book in the target culture. For example, the press reviews contribute to the construction of a certain public opinion and have "the capacity to explain, contextualize and justify a product" (Braga Riera 2018, 254). For these reasons, section 2 looks at how both source and target texts were reviewed when they first came out and to how peritexts, such as covers, may have conditioned their reception.

Since Homegoing's plot expands over several centuries and across two continents, it features several protagonists and introduces non-standard linguistic varieties to create an atmosphere of realism and to characterize each of the protagonists. Sections 3 and 4 in this paper study how Figueroa has rendered this interplay of multiple voices into Spanish and what strategies she has chosen to use to recreate the source text's literary dialects. The comparison and contrast of several fragments from Homegoing and Volver a casa show whether the otherness presented by the original novel is reflected or suppressed in the Spanish version. At this point, the notion of socio-cultural narrative should be considered, which alludes to "the everyday stories we live by [...] that change in

3 Blackness is a complex concept and here it is understood as the expression of the black experience in America, in contrast to the white cultural impositions and norms. For more insight and a philosophical approach to blackness, refer to Chapter 5: "The Fact of Blackness" in Fanon, Frantz. 2008. Black Skin, White Masks. Translated by Charles Lam Markmann. London: Pluto. 
subtle or radical ways as people experience and become exposed to new stories" (Baker 2006, 3). This refers to the stories that people tell each other about their place and history in the world to make sense of their lives, for instance, the narrative Us vs. Otherness that is explored by Homegoing and its interplay of linguistic varieties, juxtaposing standard English with the marked voice of the dispossessed protagonists.

Several scholars have studied the literary dialects portrayed in fiction and how the translator's strategies condition the portrayal of alterity in the target text. For example, Hatim and Mason $(1997,40)$ encourage the translator to study the function of linguistic varieties in the source text and they offer two alternatives, which are: rendering dialect as standard target language (standardization) or choosing a specific target dialect (parallel dialect translation). Tello Fons (2012, 143-144), on the other hand, invites translators to choose from a wider range of strategies, depending on the mimetic or symbolic role played by literary dialect in the source text. Apart from standardization and parallel dialect translation, she suggests creating a fictional dialect (pseudo-dialectal translation) and introducing a few non-standard variations and sayings-borrowed from different registersthat mark the target text (dialect compilation).

This paper follows Rica Peromingo and Braga Riera's classification (2015, 133-134) in that it builds on the previous studies by Hatim and Mason (1997) and Tello Fons (2012) and offers a comprehensive classification. These translation scholars point out that it is the translator's task to study the function of dialect in the source text and they suggest the following six strategies: dialect compilation, or a mixture of idioms and colloquial expressions from the target language that maintains the source setting; pseudo-dialectal translation, which consists of using non-standard registers from the target language to recreate a fictional non-regional variety; parallel dialect translation, in which a given regional dialect from the target language is selected; dialect localization, or the act of completely transferring dialect, cultural references and the setting to the target culture; standardization, which means rendering every linguistic variety into the normative level of target language and eliminating any trace of nonstandard dialects; and, lastly, compensation, when a few passages marked by dialect are translated into the standard and then other passages are marked in the target text to account for this loss.

Concerning slave narratives, an example of dialect compilation and pseudodialectal translation strategies would be Sanz Jiménez's translation of James McBride's The Good Lord Bird, which is titled El pájaro carpintero (2017). In the "Note on the Translation" that precedes the text, SanzJiménez $(2017,11)$ comments that he decided to play with idioms, popular sayings and widespread features of colloquial and non-standard Spanish to recreate Black English in the target novel. 
These strategies can be appreciated when the protagonist, a young black slave, describes his father's habits: "Muchas noches, vi cómo mi papa s'hinchaba a beber zumo de l'alegría y luego saltaba encima de la taberna de Henry el Holandés, pegaba tijeretazos y gritaba entre'l humo y la ginebra" (Sanz Jiménez 2017, 24). In contrast, standardization is the strategy chosen by Rodríguez Juiz in her rendering of Colson Whitehead's The Underground Railroad (2016), a novel that takes elements from nineteenth-century autobiographies by fugitive slaves and from twentieth-century neo-slave narratives. Even though the original text is marked by Black English, the slaves speak perfectly standard Spanish in El ferrocarril subteráneo: "Sabía que andabais tramando algo [...] No parabas de escabullirte con él, pero no contabas nada. iY luego vas y arrancas hasta los boniatos verdes!" (Rodríguez Juiz 2017, 66).

When it comes to parallel dialect translation, an illustrative example would be the Spanish version of Marlon James's A Brief History of Seven Killings (2015), a novel about Bob Marley's attempted assassination that resorts to eye-dialect and depicts Jamaican patois. Faced with this challenge, translators Calvo and Guerra opted for another Caribbean linguistic variety, Cuban Spanish, as can be read in their Breve historia de siete asesinatos (2016): "Todos conocemos al menos a uno, iveldá? [...] Estaba cansao de decírselo. Cansaísmo. Pero el men me soltaba esa risa suya, esa risa que se tragaba la habitación entera" (Calvo and Guerra 2016, 40). Lastly, an example of dialect localization would be translating the Black English found in, for instance, Uncle Tom's Cabin (1852) into Cuban Spanish and adapting the setting to colonial Cuba and its historical terminology, so that black characters would be enslaved at "ingenios", instead of plantations, and slavecatchers would turn into "rancheadores" (Piqueras 2011, 72).

\section{Homegoing's Context and Reception}

Homegoing is the first novel by Ghanaian American writer Yaa Gyasi, who won the PEN/Hemingway Award for debut fiction in 2017. She was born in Ghana and raised in Alabama, where she felt she did not belong. As a student, Gyasi turned to literature, eventually obtaining a BA in English at Stanford University (Wolfe 2016, n.p.). She continued her studies at the Iowa Writers' Workshop in 2012, where she began working on Homegoing. She did not rely too much on historical research, explaining that "the research wasn't crazy extensive. I say that my research was wide but shallow" (Gyasi quoted in Wolfe 2016, n.p.). She finished her first novel in 2015, her literary agent sent it to several publishers and there were ten bidders at the London Book Fair, including an astounding "sevenfigure advance that she received from Knopf" (Wolfe 2016, n.p.).

Miller (2016, n.p.) explains that the novel's title is inspired by "an old African American belief that death allowed an enslaved person's spirit to travel back 
to Africa." She deems Homegoing a breath-taking read and acknowledges that Gyasi's book is a collection of linked short stories, predisposed to anachronism, rather than a proper novel (2016: n.p.). Concerning its structure, with its intertwined chapters chronicling the lives of two Ghanaian sisters born in the eighteenth century and the fate of their descendants — up to the early twentyfirst century-, Gyasi explained in an interview how she worked on this pattern:

Initially, I had a more traditional structure in mind, one that started in presentday America and flashed back to eighteenth-century Ghana. Because I wanted this novel to be about the legacy of slavery and historical inheritance, I thought it would be sufficient to move back and forth between the first generation and the last generation, working with only four POV characters, but then I realized that I was far more interested in time, or rather [in] looking at how slavery and colonialism morphed slowly and subtly over a long period of time [...] I felt like if I could stop in every generation, from the height of the slave trade to present day, I could really help make it clear that history is not this discrete thing that happens neatly and then ends. It's dynamic; it affects everything that follows. I wanted the structure to feel like that rippling effect. (Flournoy 2016, 32-33)

Among the many influences that shape Gyasi's ambitious debut novel, Kakutani (2016, n.p.) highlights family sagas like One Hundred Years of Solitude by Gabriel García Márquez and Alex Haley's Roots, since Homegoing "sets itself the daunting task of tracing the legacy of sorrow that slavery has left on eight generations of one family" (n.p.). As the plot moves forward in time, readers witness key historical events in American history, for example the passing of the Fugitive Slave Act, the Reconstruction and the Great Migration to the North, yet it might seem that the protagonists are forced to experience these events and be representative of them. On the other hand, when the novel leaves historical landmarks aside and centers on relationships between black parents and their children, Gyasi's voice emerges as an innovative and young narrator in contemporary African American fiction. As Kakutani explains (2016, n.p.), "at those moments, we feel we are not getting a history lesson, but hearing the stories of individual men and women we have come to know and understand."

Furthermore, Homegoing has been praised as "a hugely empathic, unflinching portrayal of west Africa's role in the transatlantic slave trade" (Evans 2017, n.p.). This reviewer remarks that writing such an ambitious novel is a notable feat for a debuting author and she highlights the passages portraying relationships between black men and women as the most outstanding parts of the novel. Evans criticizes the last chapters of the novel for losing the previous seriousness, although she also acknowledges that "if there must be a purpose for the creation 
of yet another slave narrative other than to show how cruel, unfair, debased and horrific slavery was, it should be to convey the impact of it on modern life" (n.p.). In July 2020, Knopf published Yaa Gyasi's much anticipated second novel, Transcendent Kingdom, which deals with a struggling Ghanaian family living in Alabama and has received positive reviews.

The Spanish translation of Homegoing was published in March 2017 as Volver a casa by Salamandra, ${ }^{4}$ which was at the time still an independent mediumsized publisher before being bought by Penguin Random House in May 2019 (Seisdedos, Galindo and Antón 2019, n.p.). It became a fairly successful novel since, according to the Spanish ISBN database, ${ }^{5}$ Volver a casa was reprinted in July 2018 and in May 2019, a pocket edition was released in June 2019 and it was also translated into Catalan in May 2017 by Carles Andreu. ${ }^{6}$ The Spanish translation was carried out by Maia Figueroa, ${ }^{7}$ who translates books from English for several publishers, including Alianza, Destino and Seix Barral. In an interview (Hoyos 2017, n.p.), Figueroa commented that she is particularly fond of translating crime novels, such as Donna Leon's works, and science fiction, namely Jeff VanderMeer's Southern Reach saga. Salamandra published Transcendent Kingdom as Más allá de mi reino in May 2021, although it was not translated by Figueroa, but by Eduardo Hojman.

Concerning peritexts, Figure 1 below shows the different covers to Homegoing. The one on the left is the cover to the English hardback edition and it alludes to the chapters set in the United States in that it shows a black woman in shackles, who might be Esi or her daughter, Ness. She is surrounded by white cotton plants, hinting at slavery and blackness in the novel. It also features a quotation

4 Salamandra originated in 1989 as the Spanish branch of Emecé, an Argentinian publishing house. Salamandra separated from Emecé in 2000 and was managed by Pedro del Carril and Sigrid Kraus, who turned it into a medium-size company and decided to focus on contemporary fiction, crime novels and young adult books. They are responsible for publishing the Spanish version of the Harry Potter saga, which sold over twelve million books in ten years, half of them in Latin America (Seisdedos, Galindo and Antón 2019, n.p.). When Salamandra was bought by Penguin Random House in 2019, it joined Lumen, Alfaguara, Plaza y Janés and Ediciones B in becoming one the multinational's many imprints. As Seisdedos, Galindo and Antón observe (2019, n.p.), this purchase means that Penguin Random House and Planeta own over half the Spanish book market. For more information on Salamandra's origins, refer to its website at https://www.salamandra.info/origenes

5 It can be accessed at http://www.culturaydeporte.gob.es/cultura/libro/bases-de-datos-delisbn/base-de-datos-de-libros.html

6 Gyasi, Yaa. 2017. Tornar a casa. Translated by Carles Andreu. Barcelona: Salamandra Català.

7 For more details about Figueroa's career and translations, refer to her personal website at https://maiafigueroa.com/ 
by Zadie Smith—a British writer of Jamaican descent—praising Gyasi's novel. The cover in the center of Figure 1 is that of the paperback edition. It depicts Effia and Esi looking in opposite directions and there are waves at the sides, perhaps implying that these two sisters were separated by the Middle Passage and the Atlantic Ocean. This cover too includes a quotation, by African American journalist Ta-Nehisi Coates, ${ }^{8}$ who deems Homegoing "an inspiration." Lastly, the cover to Salamandra's version is the same as that of the hardcover English edition and it does not mention that Maia Figueroa is the translator-her name is only mentioned on the credits page. This book does not include any peritexts by the translator, such as a preface or footnotes, although her presence is made visible by the strategies that will be discussed in the next sections. Despite not displaying any words of praise by black authors, this cover still alludes to the blackness and slavery that target readers are going to find in the novel by reproducing the picture of a black woman in shackles surrpunded by cotton plants.

Figure 1. Covers of Homegoing (2016 and 2017)
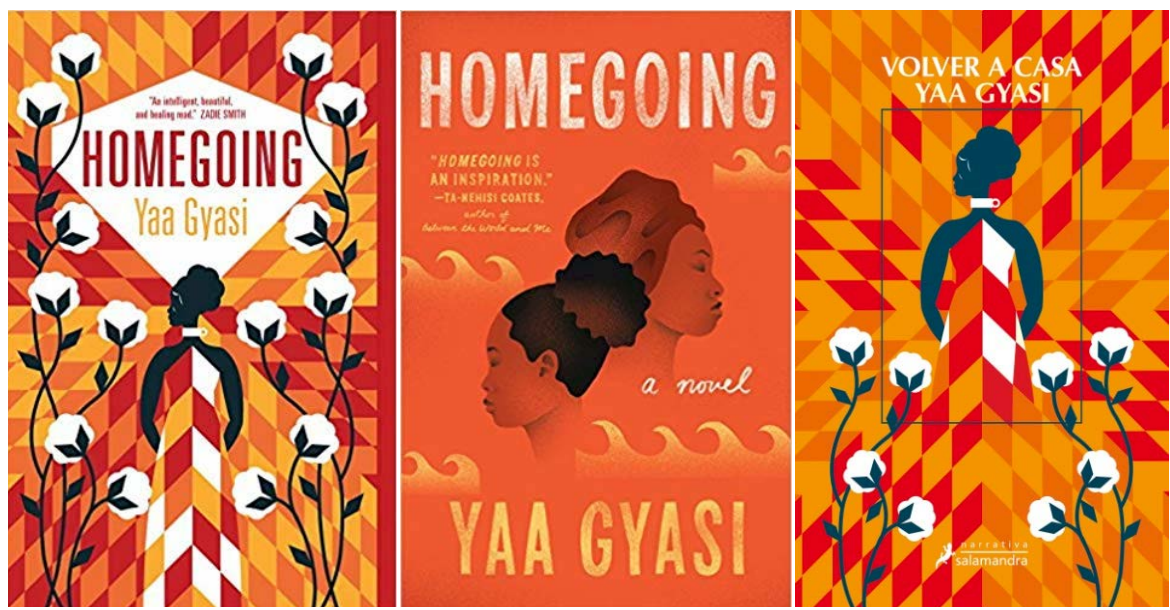

Regarding Homegoing's reception in the target culture and its epitexts, Aguilar (2017, n.p.) was surprised by Gyasi's personal story of how a Ghanaian

8 Ta-Nehisi Coates is an American journalist who wrote for The Atlantic on black citizens and white supremacy. In 2015, he was awarded the National Book Award for Non-Fiction for Between the World and Me, which encompasses his reflections on being black in the contemporary United States. Following this book's success, Coates was hired to write the Black Panther and Captain America comic-books for Marvel. 
American girl raised in Alabama turned into a successful writer and won the PEN/Hemingway Award when she was just twenty-eight. This reviewer admires how the novel covers nearly three hundred years and chronicles the lives of over a dozen protagonists, with each one featuring in a different chapter where they experience several historical events, finishing in the early 2000s (Aguilar 2017, n.p.). On the novel's complex structure, Peire (2017, n.p.) claimed that "it is striking that so many centuries and historical events can fit in four hundred pages, yet this is possible thanks to the novel's techniques, such as the use of ellipsis and time jumps." "As a result, Homegoing manages to combine stories about colonialism in Africa and slavery in the United States. It goes beyond the common ground of slave narratives and includes chapters dealing with slave trafficking within Ghana, the role different tribes ${ }^{10}$ played in it, the imposition of European languages and religions, and Ghana's fight for independence from the United Kingdom in the 1950s.

\section{Linguistic Variation in Ghana: Effia's Story}

In the chapters set in Ghana, Effia leaves her village to marry James Collins, the British commander of Cape Coast Castle, a fort on the African Gold Coast that holds the slaves who have been kidnapped before they are taken to America through the Middle Passage. Effia and James have a son, Quey, who studies in England. When he returns to Ghana, Quey tries to strengthen the trade relations between the British and his mother's village, which sells black slaves, so he decides to marry the kidnapped daughter of the Asante king. Quey's son, James, has a hectic life as he endures the wars between different tribal nations, such as the Fanta, the Asante, and the Efutu. His daughter, Abena, witnesses the introduction of cocoa plantations in Ghana and the farming revolution this involves. She leaves her village and gives her daughter, Akua, to white missionaries. Akua marries and has many children, including Yaw. While her husband is away fighting in a war, she goes insane and burns her children in their home. Yaw is the only survivor and the fire scars his face. He moves to the city, goes to university and becomes a reputed teacher. Yaw eventually marries his maid, Esther, and they have a daughter, Marjorie, before they move to the United States. Marjorie

9 This translation from Spanish into English is by the author of this paper.

10 In contrast with Roots's controversial portrayal of Europeans capturing and enslaving Africans, Homegoing's chapters set in Ghana illustrate how warring African tribes would kidnap people from rival villages and sell them as slaves to the Europeans, such as the British living at Cape Coast Castle. As Peire explains (2017, n.p.), Gyasi's novel is "not the typical story with bad white slavers, since it shows how colonizers took advantage of local tribes and manipulated them to take part in the slave trade and make a profit." 
grows up in Alabama and she has trouble at school because she is rejected by both black and white kids. She goes back to Ghana to visit her grandmother, Akua, an outcast who lives alone for having killed her children.

Homegoing showcases an omniscient third-person narrator and, when it comes to linguistic variation, in the chapters set in Ghana-those corresponding to the lives of Effia's descendants-all characters speak Standard English because they are supposedly speaking their African mother tongues, such as Twi. The example shown in Table 1 illustrates this literary resource. In it, Quey goes to his mother's village and visits his uncle, Fiifi, to talk about the business they are conducting with the British that involves slave trafficking. Both Africans are supposed to be communicating in Twi and the source text illustrates this by having them speak perfectly standard English. This does not pose any problems for the translator, who renders this fragment as standard Spanish.

TABLE 1. Translating Standard English in Ghana

\begin{tabular}{|c|c|}
\hline Gyasi 2017, 5 & Figueroa $2017,74-75$ \\
\hline $\begin{array}{l}\text { Now Fiifi was as silent as he was every } \\
\text { other time Quey had brought up trade with } \\
\text { the British. He looked out into the forest in } \\
\text { front of them, and Quey followed his gaze. } \\
\text { In the trees, two vibrant birds sang loudly, a } \\
\text { discordant song. } \\
\text { "Uncle, the agreement Badu made with } \\
\text { my father-" } \\
\text { "Do you hear that?" Fiifi asked, pointing } \\
\text { to the birds. } \\
\text { Frustrated, Quey nodded. } \\
\text { "When one bird stops, the other one } \\
\text { starts. Each time their song gets louder, } \\
\text { shriller. Why do you think that is?" } \\
\text { "Uncle, trade is the only reason we're } \\
\text { here. If you want the British out of your } \\
\text { village, you have to-" }\end{array}$ & $\begin{array}{l}\text { Y ahora Fiifi guardaba silencio, como } \\
\text { todas las veces que Quey había mencionado } \\
\text { el comercio con los británicos. Miró hacia el } \\
\text { bosque que tenían ante ellos y su sobrino } \\
\text { le siguió la mirada. Entre los árboles, dos } \\
\text { pájaros de colores llamativos competían con } \\
\text { cantos altos y discordantes. } \\
\text { —Tío, el acuerdo al que Badu llegó con } \\
\text { mi padre... } \\
\text { —iOyes eso? — preguntó Fiifi, y señaló } \\
\text { los pájaros. } \\
\text { Quey asintió con frustración. } \\
\text { —Cuando uno de los pájaros calla, el } \\
\text { otro empieza a cantar. y su canción es cada } \\
\text { vez más alta y estridente. ¿Por qué crees que } \\
\text { es así? } \\
\text { —Tío, el único motivo por el que } \\
\text { estamos aquí es el comercio. Si quieres que } \\
\text { los británicos abandonen la aldea, tienes } \\
\text { que... }\end{array}$ \\
\hline
\end{tabular}


In contrast, eye-dialect is the technique employed in Homegoing to portray the broken English spoken by two Ghanaian characters. This resource can be defined as "the attempt to depict on the printed page, through spellings and misspellings, elisions, apostrophes, syntactical shifts, signals, etc. the speech of an ethnic, regional or racial group" (Zanger 1966, 40), so the lines by characters who speak a non-standard variety are marked and contrasted with the pronunciation of Standard English. Eye-dialect can be found in Yaw's chapter, set in the 1950s, in the first fragment reproduced in Table 2. Yaw meets Esther, his new maid, and she speaks broken, non-standard English because her mother tongue is Twi and she does not have a university degree like the protagonist. However, the features that mark Esther's lines, such as misspellings and the omission of the third-person singular $-s$, have not been recreated or compensated for in Figueroa's rendering. The maid speaks standard Spanish and her alterity is assimilated by choosing to standardize her non-normative linguistic variety. Later in the book, Figueroa opts for a different strategy when Marjorie, Yaw and Esther's daughter, who has grown up in Alabama, returns to her parents' country and visits her ailing grandmother. As soon as she gets out of the airport, she meets a Ghanaian boy who is trying to take tourists sightseeing. The boy's lines omit the article the and are also marked by consonant cluster reduction-juss instead of just. Figueroa does not focus on phonological features in the target text, although she depicts the boy's poor command of Marjorie's language by reproducing the lack of articles that was present in the source novel, for instance in "te llevo a ver [el] castillo." This compensation can be appreciated as well in the third excerpt shown in Table 2, which corresponds to Homegoing's last chapter. Marjorie has taken Marcusan American friend-to Ghana and he is approached by the same boy. Once again, Figueroa compensates the Ghanaian boy's broken English by omitting the article $e l$ and mixing the second-person form perdona with the respectful form of address señor. Thanks to this strategy, the boy's linguistic variety and his alterity are reproduced in the target text, unlike in Esther's case. A tentative explanation for this different treatment may be that Esther is a major character in the novel who reappears in later chapters and gives advice to Marjorie. Marking Esther's lines when she meets Yaw would also mean introducing this linguistic variety in several subsequent chapters, when she talks to her daughter. Salamandra's publishers may be reluctant to print this abundance of non-standard language, whereas the native guide speaking in broken Spanish only shows up twice in the whole novel and his presence can be seen as anecdotal. 
TABLE 2. Translating Eye-dialect in Ghana

\begin{tabular}{|c|c|}
\hline Gyasi 2017, 229-230 & Figueroa 2017, 290-291 \\
\hline $\begin{array}{l}\text { "Ess-cuse me, sah." } \\
\text { Yaw looked up from his book. Esther } \\
\text { was standing in front of him with the long } \\
\text { handmade broom she had insisted on } \\
\text { bringing with her, even though Yaw told her } \\
\text { that this house had many brooms. } \\
\text { "You don't have to speak in English," } \\
\text { Yaw said. } \\
\text { "Yes, sah, but my sis-tah say you ah } \\
\text { teach-ah, so I must speak English." } \\
\text { She looked terrified. Her shoulders } \\
\text { hunched and her hands gripping the broom } \\
\text { so tightly that Yaw could see the area around } \\
\text { her knuckles begin to stretch and redden. } \\
\text { He wished he could cover his face, put the } \\
\text { young woman at ease. } \\
\text { "You understand Twi?" Yaw said in his } \\
\text { mother tongue, and Esther nodded. "Then } \\
\text { speak freely. We hear enough English as it is." }\end{array}$ & $\begin{array}{l}\text {-Discúlpeme, señor. } \\
\text { Yaw levantó la mirada del libro. Tenía } \\
\text { a Esther delante, con la larga escoba hecha a } \\
\text { mano que había insistido en llevar consigo a } \\
\text { pesar de que Yaw le había dicho que en su casa } \\
\text { había muchas. } \\
\text { - No hace falta que hables en inglés - } \\
\text { dijo Yaw. } \\
\text { —Sí, señor, pero mi hermana dice que } \\
\text { usted es profesor y que por eso tengo que } \\
\text { hablar inglés. } \\
\text { Parecía aterrada, con los hombros } \\
\text { hundidos y aferrándose a la escoba con tanta } \\
\text { fuerza que Yaw vio que la piel de los nudillos } \\
\text { empezaba a tensarse y enrojecerse. Le habría } \\
\text { gustado poder taparse la cara para tranquilizar } \\
\text { a la joven. } \\
\text { - iEntiendes el twi? -le preguntó en } \\
\text { su lengua natal, y Esther asintió-. Entonces, } \\
\text { habla con libertad. Ya oímos suficiente inglés. }\end{array}$ \\
\hline Gyasi 2017,265 & Figueroa 2017,332 \\
\hline $\begin{array}{l}\text { "Ess-cuse me, sistah. I take you see } \\
\text { Castle. Cape Coast Castle. Five cedis. You } \\
\text { come from America? I take you see slave } \\
\text { ship. Juss five cedis." } \\
\text { The boy was probably around ten years } \\
\text { old, only a few years younger than Marjorie } \\
\text { herself was. He had been following her since } \\
\text { she and her grandmother's housekeeper got } \\
\text { off the tro-tro. The locals did this, waiting for } \\
\text { tourists to disembark so that they could con } \\
\text { them into paying for things Ghanaians knew } \\
\text { where free. Marjorie tried to ignore him, but } \\
\text { she was hot and tired, still feeling the sweat } \\
\text { of the other people who had been pressed } \\
\text { against her back and chest and sides on the } \\
\text { nearly eight-hour tro-tro ride from Accra. } \\
\text { "I take you see Cape Coast Castle, sis. } \\
\text { Juss five cedis," he repeated. }\end{array}$ & $\begin{array}{l}\text {-Hermana. Perdona, hermana. Te llevo } \\
\text { a ver castillo. Castillo Costa del Cabo. Cinco } \\
\text { cedi. ¿Eres de América? Te llevo a ver barco de } \\
\text { esclavos. Sólo cinco cedi. } \\
\text { El chico no debía de tener más de diez } \\
\text { años, tan sólo unos pocos menos que la propia } \\
\text { Marjorie. Llevaba siguiéndola desde que se } \\
\text { había bajado del tro-tro con la empleada del } \\
\text { hogar de su abuela. Era algo que hacían los } \\
\text { lugareños: esperaban a que los turistas se } \\
\text { apeasen y trataban de enganarlos para que } \\
\text { pagasen por cosas que los ghaneses sabían que } \\
\text { eran gratuitas. Marjorie intentó no hacerle caso, } \\
\text { pero tenía calor, estaba cansada y aún notaba en } \\
\text { la piel el sudor de las otras personas que había } \\
\text { tenido pegadas a la espalda, al pecho y a los } \\
\text { costados durante el viaje de casi ocho horas en } \\
\text { tro-tro desde Accra. } \\
\text { - Te llevo a ver castillo Costa del Cabo, } \\
\text { hermana. Cinco cedi, sólo - repitió él. }\end{array}$ \\
\hline
\end{tabular}

11 The non-standard features are highlighted in bold. 


\begin{tabular}{|l|l|}
\hline Gyasi 2017, 297 & Figueroa 2017, 371 \\
\hline $\begin{array}{l}\text { "Ess-cuse me, sah! You want go see } \\
\text { slave castle? I take you see Cape Coast } \\
\text { Castle. Ten cedis, sah. Juss ten cedis. I take } \\
\text { you see nice castle." }\end{array}$ & $\begin{array}{c}\text { Cabordona, señor! iQuieres ver castillo } \\
\text { Cabor cedis sólo, señor. Diez cedis. Yo llevo } \\
\text { a ver castillo, muy bonito. }\end{array}$ \\
\hline
\end{tabular}

\section{Linguistic Variation in the United States: Esi's Story}

The second half of the novel revolves around Esi and her descendants, who have quite a different fate to those in Effia's story. Esi's village is raided by members of an enemy tribe, who murder her mother and sell Esi to the British. She is imprisoned in Cape Coast Castle, where she is tortured and raped. Esi is taken to the United States and has a daughter, Ness. The child is sold to different masters, who whip her. She meets Sam, a kind African slave, and they have a son, Kojo. With the help of the Underground Railroad, the three of them escape to the Northern states. Before being captured by slave catchers, Ness gives Kojo to her friend Ma Aku, who promises to take care of the baby boy. Ness and Sam are punished by slave catchers, but Ma Aku and Kojo make it to Baltimore.

Kojo changes his name to Jo Freeman, makes a living in Maryland and marries Anna, a free black woman. When the Fugitive Slave Act is passed in 1850, he thinks of going to the North with his son, H. However, slave catchers kidnap his wife and sell her into slavery. During the Reconstruction, $\mathrm{H}$ is imprisoned for assaulting a white woman and he is sent to work in a coal mine in inhumane conditions, where he meets a black community and reconnects with his old girlfriend, Ethe. Their daughter, Willie, marries Robert, a light-skinned black boy, and they move to Harlem. Willie is unable to get a job because of her dark skin, although Robert manages to pass as white and abandons her. Years later, their son, Carson, is involved in the Civil Rights Movement, but he becomes addicted to heroin and crack. One of Carson's children, Marcus, is a brilliant student who goes to Stanford University. There, he meets Marjorie, a Ghanaian American girl-Esther and Yaw's daughter. They become friends, travel to Ghana and visit Cape Coast Castle to reconnect with their African ancestors.

In contrast to the Standard English depicted in the chapters set in Ghana, a specific linguistic variety is introduced in Esi's story-African American English, also known as Black English. ${ }^{12}$ This literary dialect refers to "the whole

12 This paper alternates without distinction between the two denominations, Black English and African American Vernacular English. However, the features observed in Homegoing mentioned in this paper are not the only characteristics that define this linguistic variety, since there are sub-varieties and several variables that should be taken into account, like the speaker's place, time setting and sex. 
range of language varieties used by black people in the United States [...] both in cities and in rural areas, and by all age groups of both sexes" (Mufwene 2001, 291-292). As Green explains (2002, x-xi), Black English cannot be reduced to slang or mere deviations from Standard English, since it is a rulegoverned vernacular that, in works of fiction like Homegoing, "constitutes the ideal linguistic resource to create a distinctive marked discourse commonly associated with the black race identity" by the readership (Naranjo Sánchez 2015, 418). Similar to the representation of the broken English spoken by the Ghanaian characters, eye-dialect is used to depict Black English in this section of the book.

Several of its features are portrayed in Gyasi's novel and it is revealing to observe which translation strategies Figueroa has chosen to render this dialect into Spanish. One of the Black English traits found in the source text is marked negation, which means the contraction ain't is the predominant negative particle and that double negation is the rule, not an exception (Green 2002, 76; Lappin-Fortin 2016, 461). Examples of marked negation can be seen in Table 3, particularly in the lines spoken by TimTam, a kind and uneducated slave who Ness-Esi's daughter-meets when she is sold to a Southern plantation. Figueroa has resorted to pseudo-dialect translation to reconstruct TimTam's marked negation, lack of auxiliary verbs and eye-dialect. These features are recreated as marked Spanish by italicizing namás, a contraction of the vulgar pronunciation of nada plus más. This contraction does not point to a specific target regional dialect and does not replace the novel's context for a Spanish one. Instead, it lowers TimTam's register by having him use forms from non-standard Spanish. This is the same strategy Figueroa uses to recreate Black English in the second instance below. In it, Esi takes care of Pinky, a young slave girl, and gives her some advice using double negation, marked verb conjugation-it only makes - and eye-dialect. The corresponding fragment from Volver a casa shows that Ness utters contra más, a vulgar corruption of cuanto más that tends to come up in colloquial conversations and even in some Spanish written texts. ${ }^{13}$

13 On the entry corresponding to the preposition "contra," the Diccionario Panhispánico de Dudas advises against this use of contra más. See the online version at http://lema. rae.es/dpd/?key=contra. Besides, the Fundéu-the acronym for Foundation for Urgent Spanish-warns against the extensive presence of this vulgar expression in the media. See their website: https://www.fundeu.es/recomendacion/cuanto-mas-y-no-contra-mas/ 
TABLE 3. Translating Marked Negation

\begin{tabular}{|c|c|}
\hline Gyasi 2017, 76 & Figueroa 2017, 103 \\
\hline $\begin{array}{l}\text { TimTam cleared this throat and hung } \\
\text { his head a little lower. "See, we know ain't } \\
\text { nothing wrong wid her but the hiccups, but } \\
\text { we been tryin' to get to speak, so..." }\end{array}$ & $\begin{array}{l}\text { TimTam carraspeó y agachó la cabeza } \\
\text { un poco más. } \\
\text { - Mira, ya sabemos que no le pasa } \\
\text { namás que lo del hipo, pero llevamos } \\
\text { tiempo intentando que hable... }\end{array}$ \\
\hline Gyasi 2017, 79 & Figueroa 2017, 108 \\
\hline $\begin{array}{l}\text { "Don't pay dem no mind," Ness } \\
\text { whispered. "Thinking 'bout it only make it } \\
\text { worse." She didn't know if she was speaking } \\
\text { to Pinky or to herself. }\end{array}$ & $\begin{array}{l}\text { —No hagas caso —susurró Ness—. } \\
\text { Contra más lo pienses, peor. } \\
\text { No sabía si hablaba con Pinky o consigo } \\
\text { misma. }\end{array}$ \\
\hline
\end{tabular}

Regarding question formation, in African American Vernacular English there are often no auxiliary verbs in the initial position and the subject and verb are not inverted (Green 2002, 84; Rickford and Rickford 2009, 124). Marked questions are found in Homegoing as well, so there are fragments that include direct questions that show no inversion between subjects and auxiliary verbs, and these auxiliary verbs may even be omitted. This can be appreciated in the first fragment in Table 4, when Ness comes to the new plantation and TimTam asks her where she is from, leaving out the auxiliary verb are. Figueroa has recreated the black slave's literary dialect, since TimTam asks ¿de adónde? - implying destinationinstead of ide dónde? - alluding to the point of departure. This linguistic error introduces a non-normative variation in the Spanish text and marks it, so it can be classified as a combination of the strategies labelled above as dialect compilation and pseudo-dialect translation, not of localization or parallel dialect translation. However, it seems that the target text is only marked in Ness's chapter pertaining to her life under slavery, because Black English is standardized in later episodes from Gyasi's novel, as the second example shows in Table 4. It belongs to Kojo's life in Baltimore, when he is playing with his children and pretends to be a federal agent asking for the papers that show they are free blacks, preparing them for what might happen in the future. Besides, Figueroa resorts to standardization when dealing with another morpho-syntactic trait of Black English, which is the use of the personal pronoun them as a substitute for the determiner those (Rickford and Rickford 2009, 110). This marked use of them can be appreciated in the third excerpt in Table 4-together with other traits of the literary dialect under study, such as marked negation and the lack of auxiliary verbs in compound forms. It takes place in Baltimore, too, when Kojo- here he goes by his nickname Jo-and his friend fear they might by replaced by the new wave of Irish immigrants and 
lose their jobs. The corresponding passage from the target text shows that the use of them as a determiner and any other features of Black English have been completely standardized. This is a surprising choice after observing how Figueroa relied on dialect compilation and pseudo-dialect translation. If she had stuck to these two strategies, she may have opted for the vulgar form of postponing the demonstrative to the nouns, so that black characters would say uno de los irlandeses esos, similarly to the marked colloquial Spanish that Pérez de Villar introduced in her version of another neo-slave narrative, Octavia E. Butler's Kindred (Sanz Jiménez 2020, 148-149).

TABLE 4. Translating Marked Questions and Determiners

\begin{tabular}{|c|c|}
\hline Gyasi 2017, 72 & Figueroa 2017, 98 \\
\hline $\begin{array}{l}\text { "Where you comin' from?" TimTam } \\
\text { asked. He chewed the chaffy end of a wheat } \\
\text { stalk and spit. } \\
\text { "You ask too many question," Ness } \\
\text { said. }\end{array}$ & $\begin{array}{l}\text { —iDe adónde vienes? — quiso saber } \\
\text { TimTam. Masticaba un tallo seco de trigo y } \\
\text { escupía. } \\
\text { —No preguntes tanto — contestó Ness, } \\
\text { y volvió la cara, }\end{array}$ \\
\hline Gyasi 2017, 125 & Figueroa 2017, 164 \\
\hline $\begin{array}{l}\text { He would play the federal marshall } \\
\text { [sic], hands on his hips, walking up to each } \\
\text { of them, even little Gracie, and saying, in a } \\
\text { voice as stern as he could muster, "Where } \\
\text { you goin'?" }\end{array}$ & $\begin{array}{l}\text { Hacía de alguacil federal y, con los } \\
\text { brazos en jarras, se acercaba a ellos uno a } \\
\text { uno, incluso a la pequeña Gracie, y decía } \\
\text { con toda la seriedad que podía: «iAdónde } \\
\text { vas?». }\end{array}$ \\
\hline Gyasi 2017, 127 & Figueroa 2017, 167 \\
\hline $\begin{array}{l}\text { "I gotta go," Jo said to Poot, waving the } \\
\text { picture frantically, hoping the wind would } \\
\text { dry it. } \\
\text { "You can't miss no more days, Jo," Poor } \\
\text { said. "They gon' give yo job to one of them } \\
\text { Irishmen and then what, huh? Who gon' } \\
\text { feed them kids, Jo?" }\end{array}$ & $\begin{array}{l}\text {-Tengo que irme —anunció a Poot. } \\
\text { Agitaba el dibujo con desesperación, } \\
\text { esperando que el aire lo secase. } \\
\text { —No puedes faltar más días, Jo - } \\
\text { respondió su compañero-. Le ofrecerán tu } \\
\text { puesto a uno de esos irlandeses y entonces } \\
\text { ¿qué? ¿Quién dará de comer a tus críos? }\end{array}$ \\
\hline
\end{tabular}

In addition, Gyasi's novel reproduces marked verb conjugation. As Rickford and Rickford explain $(2009,114)$, this feature of Black English comprehends overgeneralization-adding the third-person singular $-s$ to other persons in present simple constructions-, omitting the final $-s$ when there is a thirdperson subject, deleting the copulative verb that joins a subject and its respective attribute-what Mufwene $(2001,299)$ terms the zero copula—and the suppression of auxiliaries in compound forms such as present perfect and continuous (Green 2002, 166). In Table 5, overgeneralization can be 
observed in the first fragment, when Margaret complains about newcomer Ness to her master, Tom Allan, and she says you is. To compensate marked verb conjugation, as well as eye-dialect and marked negation, Figueroa employs pseudo-dialect translation and adds $p a$, the short form of the preposition para that is characteristic of colloquial spoken Spanish. Consequently, Margaret's lines are marked in contrast to those of her white master, who speaks standard Spanish. Likewise, the second instance shows that Maia Figueroa relies on dialect compilation to include the colloquial idiom no pegar ojo ${ }^{14}$ - to be unable to sleep-to mark the lines uttered by black slaves who complain about Pinky's hiccups. However, the zero copula has not been compensated for through dialect compilation or pseudo-dialect translation, but rather has been standardized. For instance, when TimTam first approaches Ness, both slaves speak unmarked Spanish in the target text, as the third excerpt in Table 5 illustrates. The same strategy is used when Pinky, a mute black child, has an accident and spills water over her master's sister's dress. She is forced to apologize, Ness intercedes and tries to explain the kid is sorry, omitting the verb copula in "she is sorry," yet she speaks standard Spanish in Figueroa's rendering. The last passage in Table 5 shows the omission of auxiliary verbs in compound constructions. When Ness is aggressive to TimTam, a slave woman tries to explain that he has been through a lot, and she omits the auxiliary has when talking about TimTam. The respective lines from Volver a casa show that Figueroa has not compensated for this feature, choosing standardization to make black characters speak unmarked normative Spanish.

\section{TABLE 5. Translating Marked Verb Conjugation}

\begin{tabular}{|c|c|}
\hline Gyasi 2017, 73 & Figueroa 2017, 100 \\
\hline $\begin{array}{l}\text { "She ain't fit for da house," Margaret } \\
\text { told Tom Allan. } \\
\text { "Well, let me see her, Margaret. I'm } \\
\text { sure I can decide for myself whether or not } \\
\text { somebody's fit to work in my own house, } \\
\text { now can't I?" } \\
\text { "Yessuh," Margaret said. "I reckon you } \\
\text { is, but it ain't something you gon' want to } \\
\text { see, is what I'm sayin'." }\end{array}$ & $\begin{array}{l}\text { —No está pa trabajar en la casa - } \\
\text { anunció Margaret a Tom Allan. } \\
\text {-Deja que la vea, Margaret. Seguro } \\
\text { que puedo decidir por mí mismo si alguien } \\
\text { es adecuado para trabajar en mi casa, ino te } \\
\text { parece? } \\
\text { —Sí, señor —respondió la esclava—. } \\
\text { Seguro que puede, claro que sí. Pero lo que } \\
\text { yo digo es que no quiere ver esto. }\end{array}$ \\
\hline
\end{tabular}

14 For more details on this expression and its variants, refer to the entry on ojo in the Diccionario de la Lengua Española at: https://dle.rae.es/?w=ojo 


\begin{tabular}{|c|c|}
\hline Gyasi 2017, 79 & Figueroa 2017,108 \\
\hline $\begin{array}{l}\text { "Oh Lord, here she go! Ain't we had } \\
\text { enough trouble fo one day?" one of the } \\
\text { women said. "Can't get no kinda rest when } \\
\text { dis girl start to hiccup." }\end{array}$ & $\begin{array}{l}\text {-iSanto Dios, ya está otra vez! ¿Es que } \\
\text { no hemos tenido suficiente por un día? —se } \\
\text { quejó una de las mujeres-. Cuando le viene } \\
\text { ese hipo, no hay quien pegue ojo. }\end{array}$ \\
\hline Gyasi 20 & Figueroa 2017, 97 \\
\hline $\begin{array}{l}\text { "How's your day been?" TimTam asked. } \\
\text { Ness turned toward him just slightly. } \\
\text { "Ain't all days the same?" } \\
\text { TimTam laughed, a sound that rumbled } \\
\text { like thunder built from the cloud of his gut } \\
\text { and expelled through the sky of his mouth. } \\
\text { "I s'pose you right," he said. }\end{array}$ & $\begin{array}{l}\text { —iCómo ha ido el día? — preguntó } \\
\text { TimTam. } \\
\text { Ness se volvió hacia él, pero solo un } \\
\text { poco. } \\
\text {-Que yo sepa, todos son iguales. } \\
\text { Él se rio: el estruendo de un trueno } \\
\text { que nacía en la nube de su estómago y salía } \\
\text { disparado por el cielo de su boca. } \\
\text { —Cuánta razón... }\end{array}$ \\
\hline Gyasi 2017,78 & Figueroa 2017, 106 \\
\hline $\begin{array}{l}\text { Pinky opened her mouth, but no words } \\
\text { came out. } \\
\text { "She sorry," Ness said quickly. } \\
\text { "I wasn't talking to you," Tom Jr. said. }\end{array}$ & $\begin{array}{l}\text { La niña abrió la boca, pero de ella no } \\
\text { salió palabra. } \\
\text { - Lo siente mucho —se apresuró a } \\
\text { decir Ness. } \\
\text { —No hablo contigo — contestó Tom } \\
\text { Júnior. }\end{array}$ \\
\hline Gyasi 2017,72 & Figueroa 2017, 99 \\
\hline $\begin{array}{l}\text { "You ain't gotta be so hard on him," a } \\
\text { woman said once Ness resumed her position } \\
\text { in the field. The woman seemed older, mid } \\
\text { to late thirties, but her back hunched even } \\
\text { when she stood up straight. "You new here, } \\
\text { so you don't know. TimTam done lost his } \\
\text { woman long while ago, and he been taking } \\
\text { care of little Pinky by hisself ever since." }\end{array}$ & $\begin{array}{l}\text { - No tienes por qué ser tan dura con } \\
\text { él - le dijo una mujer cuando Ness volvió a } \\
\text { su puesto de trabajo. } \\
\text { La mujer, de entre treinta y cinco y } \\
\text { cuarenta años, parecía mayor pues tenía la } \\
\text { espalda encorvada incluso cuando se erguía. } \\
\text { —Eres nueva, por eso no lo sabes. } \\
\text { TimTam perdió a su mujer hace ya tiempo, y } \\
\text { ahora se cuida él solo de Pinky, la niña. }\end{array}$ \\
\hline
\end{tabular}

Moreover, the phonological features of African American Vernacular English are portrayed in Homegoing thanks to the eye-dialect technique commented above. Specifically, the three phonological characteristics that are most often depicted in the source text's recreation of literary dialect are the replacement of $/ \mathrm{y} /$ by /n/ in verb gerunds (Green 2002, 121; Naranjo Sánchez 2015, 423), the suppression of unstressed initial vowels (Minnick 2004, 66) and consonant cluster reduction (Rickford and Rickford 2009, 104; Lappin-Fortin 2016, 461). The latter is depicted in the two fragments shown in Table 6, which are taken from Ness's chapter at Tom Allan's plantation. In them, slaves pronounce best as bess, and told as tol'. This has been standardized in the Spanish version, yet the 
first excerpt contains an interesting strategy. TimTam is worried about Pinky, so Ruthie-another slave-recommends telling their master. Figueroa marks her intervention by including the short form pa for para and by adding the definite article el before her master's name, so that Ruthie calls him el Tom Allan. Both the short form $\mathrm{pa}$ and this use of articles before proper nouns are features of nonstandard Spanish that mark the black characters' lines, so Figueroa's strategy to recreate linguistic variety can be classified as pseudo-dialect translation.

TABLE 6. Translating Phonological Features

\begin{tabular}{|c|c|}
\hline Gyasi 2017,75 & Figueroa 2017, 103 \\
\hline $\begin{array}{l}\text { He pushed into the room, his voice choked } \\
\text { though there were no tears in his eyes. "I think } \\
\text { she got what her mama had," he said. } \\
\text { The women cleared a spot for the girl and } \\
\text { TimTam set her down before he started to pace. } \\
\text { "Oh Lord, oh Lord, oh Lord," he cried. } \\
\text { "You bess go fetch Tom Allan so's he can get } \\
\text { the doctor," Ruthie said. } \\
\text { "Doctor ain't helped last time," TimTam } \\
\text { said. }\end{array}$ & $\begin{array}{l}\text { Entró deprisa. } \\
\text { —Creoquehacogidoloquesumamá } \\
\text { —anunció con la voz estrangulada, } \\
\text { aunque tenía los ojos secos. } \\
\text { Las mujeres hicieron sitio para la } \\
\text { niña y TimTam la dejó en el suelo y se } \\
\text { puso a dar vueltas. } \\
\text { —Ay, Señor. Ay, Señor. Ay, Señor - } \\
\text { se lamentaba. } \\
\text { — Será mejor que vayas a por el } \\
\text { Tom Allan pa que avise al médico —le } \\
\text { sugirió Ruthie. } \\
\text { - La última vez el médico no sirvió. }\end{array}$ \\
\hline Gyasi 2017, 82 & Figueroa 2017, 111 \\
\hline $\begin{array}{l}\text { "They tol' me Pinky spoke yesterday. I } \\
\text { s'pose I should say thank you for that. And for } \\
\text { the other thing." }\end{array}$ & $\begin{array}{l}\text { - Me han dicho que Pinky habló } \\
\text { ayer. Supongo que debería darte las } \\
\text { gracias. Por eso y por lo otro. }\end{array}$ \\
\hline
\end{tabular}

Before closing this section, it is worth noting how Figueroa compensates a passage that is not marked by Black English in the source novel, namely the line spoken by the protagonist in defense of Pinky, who is being harassed by other slaves. Even though Ness's intervention is unmarked in Gyasi's novel, Figueroa plays with italics and pseudo-dialect translation and makes the slave say dejarla instead of dejadla in the target text. This use of the infinitive for the imperative form is a common feature of everyday colloquial Spanish, ${ }^{15}$ not necessarily characteristic of any given geographical variety. Ness's line is marked in the target text, similarly to her intervention shown in Table 3 when discussing marked negation.

15 The replacement of the imperative by the infinitive form is so widespread that even the Spanish Language Academy has written against this use, for example at https://www.rae. es/consultas/infinitivo-por-imperativo 
TABLE 7. Compensation in Volver a casa

\begin{tabular}{|c|c|}
\hline Gyasi 2017,80 & Figueroa 2017, 108 \\
\hline $\begin{array}{c}\text { Pinky squeezed her eyes tight as a series } \\
\text { of hiccups exploded from her lips. } \\
\text { "Leave her be," Ness said to the chorus } \\
\text { of groans, and they listened. }\end{array}$ & $\begin{array}{c}\text { La niña cerró los ojos con fuerza y } \\
\text { estalló en un breve ataque de hipo. } \\
\text { - Dejarla en paz —advirtió Ness al al } \\
\text { coro de protestas, y le hicieron caso. }\end{array}$ \\
\hline
\end{tabular}

\section{Concluding Remarks}

Regarding literary dialects, there are two separate parts in Homegoing. In the chapters chronicling the lives of Effia and her descendants that are set in Africa, characters are supposed to be speaking their African mother tongues, such as Twi, so the source text is written in Standard English and does not pose any additional challenges for Figueroa. Still, there are a couple of African characters-Esther and a boy-who speak broken English in a few fragments and this variety is contrasted with the protagonists' normative language. Esther's lines are standardized by Figueroa, but the boy's interventions are marked thanks to compensation, a strategy that reflects his alterity in the target text, as seen in Table 2 above.

The chapters focusing on Esi's family and their ordeals in America deal with the oppression of African Americans in the United States, including slavery, and they portray several morpho-syntactic and phonological traits of Black English. When Figueroa deals with this linguistic variety in Gyasi's novel, she alternates between pseudo-dialect translation, dialect compilation and compensation and recreates the slaves' linguistic variety by including shorts forms $(p a)$, contractions (namás), and idioms from colloquial Spanish (no pegar ojo), together with a series of vulgar misuses, for instance adding an article before a proper noun (El Tom Allan) and replacing an imperative with an infinitive (dejarla en paz). By playing with spelling and introducing characteristics from non-standard Spanish, Figueroa succeeds in reflecting the otherness represented by dispossessed slaves and at contrasting it with white people's position of power and possession, since masters tend to speak Standard English. As such, the narrative Us vs. Otherness that is present in Homegoing is reproduced in Volver a casa, too, through the interplay of characters' voices and linguistic varieties that deviate from standard conventions.

Despite this achievement, it is pertinent to point out that alternative strategies to standardization-namely, compensation, pseudo-dialect translation, and dialect compilation-only come up in Ness's chapter, the one set in the Southern plantation. This may be related to the emerging convention of playing with nonstandard linguistic varieties as a way of giving the dispossessed characters in neo-slave narratives their own voice, as Sanz Jiménez considers in his study 
on the Spanish translations of Flight to Canada and Kindred (2020, 151-152). Although African American English also comes up in the lines spoken by black characters in the chapters focusing on Kojo and $\mathrm{H}$-which are set in the 1850s and the Reconstruction, respectively-, this literary dialect becomes unmarked Spanish in Figueroa's rendering. This means that passages playing with spelling and deviating from the standard norm in the target text are limited to Ness's chapter at Tom Allan's plantation (Gyasi 2017, 70-87; Figueroa 2017, 96-117). It is interesting, though, that Maia Figueroa managed to include alternatives to standardization in a novel that was published by Salamandra, a medium-size publishing house that had not yet been absorbed by Penguin Random House in Spring 2017, when Volver a casa came out. Now that Salamandra is an imprint that belongs to a multinational group, it is not clear whether the publishing policies would allow for the inclusion of fragments in non-standard Spanish. As seen at the end of the Introduction, precedents like El ferrocarril subterráneo hint at Random House's preference for unmarked Spanish in neo-slave narratives, perhaps as a way of reaching a broader target readership.

As an extension to the current work, the strategies that were chosen by Carles Andreu to render linguistic varieties into Catalan and whether they match those employed by Figueroa could be studied. Besides, it would be most interesting to analyze Más allá de mi reino (2021) and Hojman's translation. Future studies could focus on how the alterity depicted in Gyasi's second novel has been translated into Spanish, as it centers on a Ghanaian American family making a living in Alabama in the late twentieth and early twentyfirst centuries. It would be revealing, too, to observe whether the fact that Salamandra now belongs to a multinational publishing group affects the choice of translation strategies for dealing with non-standard linguistic varieties and the Other's voice. The description of the translation strategies used to deal with the linguistic varieties spoken by the dispossessed may serve as the basis for analyzing translation trends, the reasons why other alternatives are not employed when they are theoretically available, and the significant role played by patrons in the implementation of these strategies, as well as in the portrayal of alterity in the target culture.

\section{Works Cited}

AguiLAR, Andrea. 2017. "Tanto el sueño como la pesadilla pueden ser ciertos en EE UU." El País. https://elpais.com/cultura/2017/03/10/actualidad/1489142161_693904. html [Accessed online on September 10, 2019]

Algeo, John, ed. 2001. The Cambridge History of the English Language: English in North America. Cambridge: Cambridge UP. 
BAKer, Mona. 2006. Translation and Conflict: A Narrative Account. London: Routledge. Braga Riera, Jorge. 2018. "The Role of Epitexts in Drama Translation.” JoSTrans. The Journal of Specialised Translation 30: 249-268.

Calvo, Javier and Wendy Guerra, translators. 2016. Breve historia de siete asesinatos. By Marlon James. Barcelona: Malpaso.

Dubey, Madhu. 2010. "Neo-Slave Narratives." In Jarrett 2010, 332-346.

Evans, Diana. 2017. "Homegoing by Yaa Gyasi Review: The Wounds Inflicted by Slavery." The Guardian. https://www.theguardian.com/books/2017/jan/13/ homegoing-by-yaa-gyasi-review. [Accessed online on May 8, 2019]

FigueroA, Maia, translator. 2017. Volver a casa. By Yaa Gyasi. Barcelona: Salamandra. Flournoy, Angela. 2016. "Yaa Gyasi." Poets E Writers 44(4): 32-33.

Genette, Gérard. 1997. Paratexts: Thresholds of Interpretation. Translated by Jane E. Lewin. Cambridge: Cambridge UP.

Green, Lisa J. 2002. African American English: A Linguistic Introduction. Cambridge: Cambridge UP.

GyasI, Yaa. 2017. Homegoing. New York: Vintage.

Hatım, Basil and Ian Mason. 1997. Discourse and the Translator. London: Longman.

Hermans, Theo, ed. 1985. The Manipulation of Literature: Studies in Literary Translation. London: Croom Helm.

Hoyos, Isabel. 2017. "Mucho más que una traductora de serie negra: Entrevista a Maia Figueroa." La linterna del traductor: La revista multilingüe de ASETRAD. http://www.lalinternadeltraductor.org/n15/maia-figueroa.html [Accessed online on February 25, 2020]

JarRett, Gene Andrew, ed. 2010. A Companion to African American Literature. Oxford: Wiley-Blackwell.

KaKUTANi, Michiko. 2016. "In Homegoing, What Slavery Costs One Family." The New York Times. https://www.nytimes.com/2016/06/14/books/review-homegoing-byyaa-gyasi.html [Accessed online on February 26, 2020]

Lappin-Fortin, Kerry. 2016. "Traduire Le Black English ('C'est Comme Ça Des Fois.')." Meta 61(2): 459-478. https://doi.org/10.7202/1037768.

Miller, Laura. 2016. "Descendants: A Sprawling Tale of a Family Split between Africa and America." The New Yorker. https:/www.newyorker.com/ magazine/2016/05/30/yaa-gyasis-homegoing [Accessed online on May 8, 2019] Minnick, Lisa. 2004. Dialect and Dichotomy: Literary Representations of African American Speech. Tuscaloosa: U of Alabama P.

Mufwene, Salikoko S. 2001. "African-American English." In Algeo 2001, 291-324.

Naranjo SÁnchez, Beatriz. 2015. "Translating Blackness in Spanish Dubbing." Revista

Española de Lingüística Aplicada 28(2): 416-441. https://doi.org/10.1075/ resla.28.2.03nar. 
PeIRE, Carmen. 2017. “Cara y cruz de la esclavitud.” InfoLibre. https://www.infolibre.es/ noticias/los_diablos_azules/2017/12/15/volver_casa_yaa_gyasi_73092_1821. html [Accessed online on September 10, 2019]

PiQueras, José Antonio. 2011. La esclavitud en las Españas: Un lazo transatlántico. Madrid: Catarata.

Rica Peromingo, Juan Pedro and Jorge Braga Riera. 2015. Herramientas y Técnicas para la traducción inglés-español: Los textos literarios. Madrid: Escolar y Mayo.

RickFord, John Russell and Russell John Rickford. 2009. Spoken Soul: The Story of Black English. New York: John Wiley and Sons.

Rodriguez, Junius P., ed. 2007. Slavery in the United States: A Social, Political, and Historical Encyclopedia. Santa Barbara (CA): ABC-CLIO.

RodríGuez Juiz, Cruz, translator. 2017. El ferrocarril subterráneo. By Colson Whitehead. Barcelona: Random House.

Rushdy, Ashraf H. A. 1992. "The Phenomenology of the Allmuseri: Charles Johnson and the Subject of the Narrative of Slavery." African American Review 26(3): 373385.

SAnZ JimÉnez, Miguel, translator. 2017. El pájaro carpintero. By James McBride. Gijón: Hoja de Lata.

-. 2020. "Flight to Canada and Kindred: Similarities and Discrepancies in Two NeoSlave Narratives Translated into Spanish." The Grove: Working Papers on English Studies 27: 135-156. https://doi.org/DOI: 10.17561/grove.v27.a9.

Seisdedos, Iker, Juan Carlos Galindo, and Jacinto Antón. 2019. "La venta de Salamandra acentúa la concentración editorial.” El País. https://elpais.com/ cultura/2019/05/03/actualidad/1556875349_555619.html [Accessed online on February 25, 2020]

Tello Fons, Isabel. 2012. "Traducción de la variación lingüística: Una visión diacrónica”. Hikma: Revista de Traducción 11: 133-159. https://doi.org/10.21071/ hikma.vl li.5249

Toury, Gideon. 1985. "A Rationale for Descriptive Translation Studies." In Hermans 1985, 16-41.

Wolfe, Eli. 2016. "How Yaa Gyasi Found Her Story in Slavers' Outpost." San Francisco Chronicle. https://www.sfgate.com/books/article/How-Yaa-Gyasi-found-her-storyin-slavers-8329849.php [Accessed online on February 25, 2020]

ZANGER, Jules. 1966. "Literary Dialect and Social Change". Midcontinent American Studies Journal 7(2): 40-48. 